Jurnal Penelitian Pendidikan Geografi Volume 4 No. 1 Januari 2019

\title{
DESKRIPSI KONDISI SOSIAL EKONOMI MASYARAKAT NELAYAN DI DESA LAKARINTA KECAMATAN LOHIA KABUPATEN MUNA
}

\author{
${ }^{1}$ Siti Alfisa
}

\author{
${ }^{1}$ Alumni Pendidikan Geografi FKIP Universitas Halu Oleo
}

\begin{abstract}
Abstrak: Penelitian ini bertujuan untuk mengetahui keadaan sosial ekonomi masyarakat nelayan di Desa Lakarinta Kecamatan Lohia Kabupaten Muna. Jenis penelitian ini adalah jenis penelitian deskriptif kualitatif. Teknik pengumpulan data yang di gunakan adalah angket/kuisioner dan dokumentasi. Data di peroleh dari 23 informan. Keadaan sosial ekonomi dilihat dari pendidikan responden tergolong tingkat rendah yaitu 60,84\%,karena pendidikan mereka masih sampai jenjang SD, dilihat pada perumahan responden sudah di kategorikan sedang karena dari 23 responden 9 responden sudah memiliki semi permanen, pada tingkat kesehatan respondenbaik karena memilih berobat di Puskesmas serta tenaga medis lainnya dibandingkan dengan berobat di dukun, dilihat dari presentase tidak ada yang memilih berobat di dukun, dari segi pendapatan masyarakat nelayan yang ada di Desa Lakarinta Kecamatan Lohia Kabupaten Muna dari informasi yang di peroleh dari responden rata-rata mereka memiliki pendapatan $\geq \mathrm{Rp}$. $3.000 .000 \%$ setiap bulannya atau sebesar $43,47 \%$.

Kata Kunci : Masyarakat Nelayan, Proses, Kondisi Ekonomi.
\end{abstract}




\title{
DESCRIPTION OF THE SOCIAL ECONOMIC CONDITIONS OF THE FISHERMEN'S COMMUNITY IN LAKARINTA VILLAGE LOHIA DISTRICT MUNA REGENCY
}

\author{
${ }^{1}$ Siti Alfisa \\ ${ }^{1}$ Alumni Of Halu Oleo University Geography Education
}

\begin{abstract}
This study aims to determine the social economic conditions of the fishing community in Lakarinta Village Lohia District Muna Regency. This type of research is a type of qualitative descriptive research. Data collection techniques that are used are questionnaires / questionnaires and documentation. Data obtained from 23 informants. Socioeconomic conditions seen from the respondents' education were classified as low levels of $60.84 \%$, because their education was still at the elementary level, seen in the respondents housing was categorized moderate because of the 23 respondents 9 respondents already had semi-permanent, the respondent's health level was good because of choosing treatment at the Puskesmas and other medical personnel compared to treatment at the dukun, judging from the percentage no one chose to seek treatment at the dukun, in terms of the income of the fishing community in Lakarinta Village Lohia District Muna Regency the information obtained from the average respondent they had income $\geq$ Rp. 3,000,000\% every month or $43.47 \%$.
\end{abstract}

\section{Keywords: Fisherman Community, Process, Economic Conditions}

\section{PENDAHULUAN}

Masyarakat nelayan merupakan salah satu bagian masyarakat yang hidup dengan mengelola potensi sumber daya perikanan. Sebagai suatu masyarakat yang tinggal di kawasan pesisir, masyarakat nelayan mempunyai karakteristik sosial tersendiri yang berbeda dengan masyarakat yang lain. Di beberapa kawasan pesisir yang relatif berkembang pesat, struktur masyarakat bersifat heterogen, memiliki etos kerja yang tinggi, solidaritas yang kuat, serta terbuka terhadap perubahan dan interaksi sosial.

Mata pencaharian nelayan bisa dikatakan sebagai sesuatu pekerjaan yang turun-temurun.Sebagai nelayan, penghasilan yang didapatkan tidaklah tetap, bisa dikatakan rezeki yang didapatkan nasib-nasiban karena nelayan mengandalkan hasil alam serta kondisi alam, seperti cuaca, angin, dan keadaan bulan, purnama atau tidak.Fasilitas dan peralatan nelayan yang masih tradisionalpun mempengaruhi penghasilan para nelayan. Tidak menentunya penghasilan yang didapatkan oleh nelayan-nelayan ini berdampak pada kesejahteraan keluarga.

Masyarakat nelayan dapat dipandang sebagai suatu lingkungan hidup dari satu individu atau satu keluarga nelayan. Dengan katalain masyarakat nelayan dibentuk oleh sejumlah rumah tangga nelayan dan tiap rumah tangga merupakan lingkungan hidup bagi yang lainnya (Mantjoro,1995). Kehidupan masyarakat nelayan adalah keadaan nyata yang dapat diungkapkan melalui usaha mereka yang dipengaruhi oleh musim penangkapan ikan, kondisi alam tidak menunjang, terbatasnya modal dan tingkat pendidikan yang rendah sehingga mengakibatkan keadaan sosial ekonomi lemah. Nelayan di Desa LakarintaKecamatan Lohia Kabupaten Muna, kebanyakan masih menggunakan 
alat tangkap soma dampar, pancing ulur, dan pukat cincin sebagai alat tangkap utama yang dilakukan secara turun temurun. Sebenarnya mereka ingin mencoba alat tangkaplain yang lebih modern dan efisien tapi karena keterbatasan modal yang dimiliki maka mereka hanya dapat bertahan dengan alat tangkap yang ada.

Nelayan di Desa Lakarinta ini tidak semata-mata hanya bergantung kepada toke dalam memenuhi kebutuhan mereka.Hasil tanggkapan yang diperoleh nelayan bisa saja hanya untuk memenuhi kebutuhan sehari-hari misalnya dijadikan lauk pauk bagi kelurga nelayan. Tetapi jika hasil tangkapan nelayan banyak maka bisa dijajakan keliling kampung atau disetor ketoke di pasar tradisional Muna. Pengasilan perbulan yang didapat oleh para nelayan di desa ini juga bisa dikatakan lumayan mencukupi kebutuhan jika aktivitas bekerjanya lancar dan musim ikan berlangsung lama. Berdasarkan observasi awal nelayan didesa ini bisa menghasilkan pendapat perbulan kotornya sebanyak Rp.3.000.000 dapat diperkirakan hasil pendapatan perbulan mereka adalah kurang lebih banyak Rp.2.500.000, diluar uang perbaikan kapal, perbaikan alat penangkap ikan dan lain-lain. Jam kerja nelayan di perkampungan ini yaitu dimulai dari pukul 04.00 hingga pukul 11.00 pagi.

Berdasarkan hasil observasi awal menunjukan tingkat kehidupan sosial ekonomi Masyarakat nelayan di Desa Lakarinta sudah mengalami peningkatan. Hal ini ditandai dengan kondisi rumah hunian mereka dimana sebagian atau lebih banyak sudah tidak menggunakan rumah semi permanen tetapi sudah memiliki rumah permanen dan bahkan kebanyakan para orang tua sudah menyadari arti pentingnya anak-anak mereka untuk memperoleh pendidikan.

Berdasarkan uraian diatas dimana data awal menunjukan bahwa masyarakat nelayan yang ada di Desa Lakarinta Kecamatan Lohia Kabupaten Muna menunjukan peningkatan taraf hidup yang lebih baik. Untuk mengetahui kondisi mereka lebih detail khususnya dari bentuk rumah, pendidikan, kesehatan dan juga pendapatan, membutuhkan penelitian lebih dalam, oleh karena itu penulis tertarik untuk mengungkap kondisi sosial ekonomi oleh masyarakat nelayan dengan judul: "Deskripsi Kondisi Sosial Ekonomi Masyarakat Nelayan di Desa Lakarinta Kecamatan Lohia Kabupaten Muna”.

\section{METODE PENELITIAN}

Penelitian ini telah dilaksanakan di Desa Lakarinta Kecamatan Lohia Kabupaten Muna dari tanggal 18-08 juli 2018 sampai selesai.

Populasi dalam penelitian ini adalah seluruh kepala keluarga nelayan di Wilayah Desa Lakarinta, Kecamatan Lohia, Kabupaten Muna sebanyak 23 orang dan jumlah populasi tidak banyak atau 23 orang, maka sampel penelitian diambil sebanyak anggota populasi yang biasanya disebut sampel total.

Jenis data primer terdiri dari: pendapatan, pendidikan, perumahan, dan kesehatan.Jenisdata sekunder terdiri dari keadaan alam, jumlah penduduk, potensi ekonomi Desa Lakarinta sarana dan prasarana sosial ekonomi masyarakat nelayan.

Data yang digunakan dalam penelitian ini yaitu data primer dan data sekunder.Data primer merupakan data yang di peroleh secaralangsung dari responden penelitian.Sedangkan data sekunder berasal dari pemerintah setempat.

Variabel yang berkaitan dengan sosial meliputi: a Pendidikan, b Perumahan, c Kesehatan. Selanjutnya variabel yang berkaitan dengan ekonomi seperti:(a) Mata Pencaharian, (b) Pendapatan

Terdapat dua teknik pengumpulan data yang digunakan pada penelitian ini, 
teknik pengumpulan data tersebut antara lain: Observasi, Angket atau kuesioner dan Dokumentasi.

Analisis data adalah proses mencari dan menyusun secara sistematis dan yang di peroleh dari hasil angket dan dokumentasi. Teknik analisis data yang digunakan adalah teknik deskriptif kualitatif,sesuai dengan kebutuhan yang menjelaskan tentang keadaan sesungguhnya mengenai Deskripsi Kondisi Sosial Ekonomi Masyarakat Nelayan di Desa Lakarinta Kecamatan Lohia Kabupaten Muna.
Instrumen penelitian ini digunakan sebagai acuan dalam pengumpulan data yang dilakukan dengan memberikan pertanyaan kepada responden untuk Deskripsi Kondisi Sosial Ekonomi Mayarakat Nelayan.

\section{HASIL PENELITIAN}

\section{A. KARATERISTIK RESPONDEN}

\section{Berdasarkan Umur}

Apabila di lihat dari segi umur, masyarakat nelayan yang di jadikaansebagai responden dapat di lihat pada tabel sebagai berikut :

Tabel 4.1 Klasifikasi Umur Responden

\begin{tabular}{cccc}
\hline No & Umur (Tahun) & Jumlah & Persentase(\%) \\
\hline 1 & $26-36$ & 8 & 34,7 \\
\hline 2 & $37-46$ & 6 & 26,2 \\
\hline 3 & $47-62$ & 9 & 39,1 \\
\hline & Jumlah & $\mathbf{2 3}$ & $\mathbf{1 0 0}$ \\
\hline
\end{tabular}

Sumber: Data Primer Desa Lakarinta (2018)

Dari tabel diatas terlihat bahwa jumlah responden dari umur 26-36 tahun sebanyak 8 atau sebesar 34,7\%,kemudian umur 3746 tahun sebanyak 6 atau sebesar $26,2 \%$, sedangkan umur 47-60 sebanyak 9 atau sebanyak 39,1\%.

2. Tingkat Pendidikan Responden

Tingkat pendidikan adalah jenjang pendidikan formal yang telah di selesaikan sampai mendapatkan keterangan lulus. Tingkat pendidikan turut mempengaruhicara berpikir dan bertindak seseorang. Pendidikan yang cukup tinggi mengakibatkan seseorang lebih dimana mengambil keputusan ketika melakukan kegiatannya, adapun tingkat pendidikan yang dimaksud dalam penelitian ini adalah jenjang pendidikan formal yang telah dilalui oleh responden.

memiliki tingkat pendidikan dimana tidak tamat SD sebanyak 4 responden atau sebesar 17,39\%, Tamat SD sebanyak 14 responden atau sebesar 60,86\%, kemudian Tamat SMP sebanyak 3 responden atau sebesar 13,04\%, kemudian Tamat SMA sebanyak 2 responden atau sebesar 8,71, sedangkan Tamat Perguruan Tinggi tidak ada.

\section{B. HASIL ANALISIS KONDISI SOSIAL EKONOMI MASYARAKAT NELAYAN}

1. Tingkat Pendidikan Responden

Tingkat pendidikan adalah jenjang pendidikan formal yang telah di selesaikan sampai endapatkan keterangan lulus. Tingkat pendidikan turut mempengaruhicara berpikir dan bertindak seseorang. Pendidikan yang cukup tinggi mengakibatkan seseorang lebih dinamis dalam mengambil keputusan ketika melakukan kegiatannya. Adapun 
tingkat pendidikan yang dimaksud dalam penelitian ini adalah pendidikan responden selama menjadi masyarakat nelayan.
Untuk memengetahui tingkat pendidikan responden akan di gambarkan dalam tabel berikut ini:

Tabel 4.2 Tingkat Pendidikan Responden

\begin{tabular}{clcc}
\hline No & Tingkat Pendidikan & Jumlah & Persentase(\%) \\
\hline 1 & Tidak Tamat SD & 4 & 17,39 \\
\hline 2 & Tamat SD & 14 & 60,86 \\
\hline 3 & Tamat SMP & 3 & 13,04 \\
\hline 4 & Tamat SMA & 2 & 8,71 \\
\hline 5 & Tamat Perguruan Tinggi & - & - \\
\hline & Jumlah & $\mathbf{2 3}$ & $\mathbf{1 0 0}$ \\
\hline
\end{tabular}

Sumber: Data Primer Desa Lakarinta (2018)

Dari tabel diatas menunjukan bahwa responden umumnya memiliki tingkat pendidikan dimana Tidak Tamat SD sebanyak 4 responden atau sebesar $17,39 \%$,Tamat SD sebanyak 14 responden atau sebesar60,86\%, kemudian Tamat SMP sebanyak 3 responden atau sebesar 13,04\%, kemudian Tamat SMA sebanyak 2 responden atau sebesar $8,71 \%$ sedangkan Tamat Perguruan Tinggi tidak ada.

2. Kondisi Kesehatan Responden

Kondisi kesehatan meliputi kondisi fisik, mental dan lingkungan suatu masyarakat jelas terikat dengan keberadaan pola hidup yang di tampilkan oleh masyarakat yang bersangkutan. Kesehatan adalah salah satu unsur penting dalam hidup, karena dengan kondisi kesehatan yang baik maka aktivitas untuk menjalankan kehidupan sehari-hari dalam mencari nafkah akan berjalan dengan lancar. Sebaliknya seseorang dalam kondisi yang kurang sehat maka aktivitas sehari-hari akan terganggu.

Keluarga dengan status sosial yang tinggi akan berobat pada tempat yang mahal dan tidak khawatir dengan biaya yang tinggi. Responden hanya akan berobat kepuskesmas apabila penyakit yang diderita kompleks atau parah. Kebiasaan yang terjadi adalah seringnya membeli obat di kios tanpa resep dokter. Berdasarkan hasil angket yang telah di bagikan mereka akan berobat ke puskesmas, bidan atau tenaga medis apabila ada yang sakit parah atau luka parah. Biasanyapenyakit yang sering menyerang mereka adalah sakit pinggang, demam dan batuk-batuk. Mengenai tingkat kesehatan responden yang sakit 6 bulan terakhir dapat dilihat pada tabel berikut:

Tabel 4.3. Tingkat Kesehatan Responden

\begin{tabular}{cccc}
\hline No & Kondisi Kesehatan & Jumlah & Persentase (\%) \\
\hline 1 & Sangat baik & - & - \\
\hline 2 & Baik & 19 & 82,60 \\
\hline 3 & Kurang baik & 4 & 17,39 \\
\hline 4 & Buruk & - & - \\
\hline & Jumlah & $\mathbf{2 3}$ & $\mathbf{1 0 0}$ \\
\hline
\end{tabular}

Sumber: Data Primer Desa Lakarinta(2018) 
Data diatas menunjukan bahwa pada umumnya responden yaitu $82,60 \%$ mempunyai kondisi kesehatan yang baik, yang meliputi kesehatan keluarga, lingkungan dan masyarakat. Namun demikian terdapat pula responden yaitu17,39\% yang mempunyaikondisi kesehatan yang kurang baik, terutama kondisi kearah baik dan bila ditinjau dari kondisi kesehatan lingkungan keluarga dan masyarakat. Pada kesehatan lingkungan keluarga.

Dari data yang diperoleh diatasdapat dikatakan bahwa kondisi kesehatan masyarakat nelayan di Desa Lakarinta Kecamtan Lohia relatif sudah baik dan bila ditinjau dari kondisi kesehatan lingkungan keluarga dan masyarakat. Pada umumnya masyarakat sudah memiliki kesadaran tinggi akan pentingnya hidup sehat dalam usaha meningkatkan produktivitas kerja. Hal ini dapat di lihat dengan adanya kesadaran masyarakat untuk menyediakan berbagai fasilitas kesehatan di rumah seperti WC umum dan sebagainya.

Adanya perilaku masyarakat untuk memperhatikan aspek kesehatan di rasakan telah membawa dampak positif untuk masyarakat nelayan di Desa Lakarinta Kecamatan Lohia. Keadaan ini dapat dilihat dari jarangnya anggota keluarga yang terserang penyakit yang bersumber dari kotoran lingkungan seperti penyakit kulit, gatal-gatal, diare, malaria, dan penyakit lainnya. Sebagaiman pernyataan responden sebagai berikut:

Tabel 4.4. Pernyataan Responden Mengenai Sering Tidaknya Anggota Keluarga yang Terserang Penyakit

\begin{tabular}{cccc}
\hline No & Pernyataan Responden & Jumlah & Presentase (\%) \\
\hline 1 & Sangat sering & - & - \\
\hline 2 & Sering & - & - \\
\hline 3 & Kadang-kadang & 7 & 30,43 \\
\hline 4 & Tidak pernah & 16 & 69,57 \\
\hline & Jumlah & $\mathbf{2 3}$ & $\mathbf{1 0 0}$
\end{tabular}

Sumber: Data Primer Desa Lakarinra (2018)

Dari data tersebut dapat di ketahui pernyataan responden mengenai sering tidaknya anggota keluarga terserang penyakit yang bersumber dari lingkungan, dimana terdapat sebanyak 16 responden atau responden $69,57 \%$ yang tidak terserang penyakit yangbersumber dari lingkungan, sedangkan 7 responden atau sebesar $30,43 \%$ yang menyatakan kadangkadang anggota keluarga terserang penyakit.

Dari uraian diatas memberikan gambaran bahwa masyarakat nelayan sangat memperhatikan aspek kesehatan sebagai salah satu cara untuk meningkatkan kondisi sosial masyarakat.
Keadaan ini terlihat dengan semakin kurangnya anggota keluarga yang diserang oleh penyakit yang bersumber dari lingkungan.

Dari hasil penelitian dilapangan menunjukan bahwa keadaan kesehatan masyarakat telah memiliki kesadaran tentang pemanfaatan jasa atau pelayanan pusat kesehatan masayarakat (puskesmas) pada umumnya masyarakat bila terserang penyakit selalu berobat ke puskesmas atau pada petugas kesehatan yang ada. Adapun beberapa jenis penyakit yang di alami oleh masyarakat adalah penyakit kulit, gatal-gatal, diare, batuk-batuk dan penyakit malaria. 
Jurnal Penelitian Pendidikan Geografi Volume 4 No. 1 Januari 2019

Berikut ini penulis akan berobat responden bila terserang menyajikan sikap responden terhadap penyembuhan penyakit atau sarana

penyakit

Tabel 4.5. Sarana Berobat Responden Apabila Terserang Penyakit

\begin{tabular}{cccc}
\hline No & Sarana berobat & Jumlah & Persentase (\%) \\
\hline 1 & RSUD & - & - \\
\hline 2 & Puskesmas & 23 & 100 \\
\hline 3 & Bidan & - & - \\
\hline 4 & Dukun & - & - \\
\hline & Jumlah & $\mathbf{2 3}$ & $\mathbf{1 0 0}$
\end{tabular}

Sumber: Data Primer Desa Lakarinta (2018)

Dari tabel diatas menunjukan bahwa sebanyak 23 responden atau sebesar $100 \%$ pada umunya merekaberobat di puskesmas yang ada di Desa Lakarinta.

\section{Status Kepemilikan Rumah}

Rumah merupakan salah satu bagi kehidupan manusia dimana merupakan kebutuhan dasar yang harus dipenuhi oleh mahluk hidup yang berpikir, karena fungsi bagi masyarakat tidak hanya sekedar pemenuhan kebutuhan tempat tinggal atau tempat berlindung saja akan tetapi diselaraskandengan kebutuhan lain seperti keamanan dan kenyamanan dalam lingkungan keluarga maupun masyarakat sekitarnya.

Berdasarkan hasil penelitian dilapangan menunjukan status kepemilikan rumah yang sedang ditempati oleh responden adalah milik sendiri.Untuk lebih jelasnya status kepemilikan rumah yang di tempati responden, dapat di lihat pada tabel sebagai berikut:

Tabel 4.6. Status Kepemilikan Rumah Responden

\begin{tabular}{cccc}
\hline No & Kepemilikan Rumah & Jumlah & Persentase (\%) \\
\hline 1 & Milik sendiri & 20 & 86,95 \\
\hline 2 & Sewa & 3 & 13,05 \\
\hline 3 & Menumpang & - & - \\
\hline & Jumlah & $\mathbf{2 3}$ & $\mathbf{1 0 0}$ \\
\hline
\end{tabular}

Sumber: Data Primer Desa Lakarinta(2018)

Berdasarkan hasil penelitian di lapangan dimana menunjukan bahwa status kepemilikan rumah responden yaitu rumah yang di tempati merupakan milik sendiri. Hal ini menunjukan bahwa status kepemilikan rumah yang ditempati responden bukan lagi masih menumpangatau masih kontrak tetapi mereka sudah mempunyai rumah sendiri sehingga dapat disimpulkan bahwa status kepemilikan rumah dapat dikategorikan baik.

\section{Sumber Penerangan Rumah Responden}

Berdasarkan hasil penelitian di lapangan menunjukan bahwa penerangan yang digunakan responden adalah menggunakan penerangan dari listrik PLN. Untuk lebih jelasnya dapat dilihat pada tabel berikut 
Tabel 4.6. Sumber Penerangan

\begin{tabular}{cccc}
\hline No & Sumber penerangan & Jumlah & Persentase(\%) \\
\hline 1 & PLN & 23 & 100 \\
\hline & Jumlah & $\mathbf{2 3}$ & $\mathbf{1 0 0}$ \\
\hline
\end{tabular}

Sumber:Data Primer Desa akarinta (2018)

Berdasarkan tabel diatas menunjukan bahwa rumah yang di tempati oleh responden menggunakan penerangan dari PLN dengan demikian dapat disimpulkan bahwa penerangan yang digunakan oleh responden di kategorikan baik karena semua responden menggunakan listrik dari PLN.
Selain aspek kepemilikan rumah, luas bangunan rumah yang paling diperhatikan juga adalah kondisi fisik bangunan, hal yang dapat dilihat dari aspek perumahan yaitu kondisi fisik bangunan rumah yang dimiliki oleh responden. Adapun kondisi fisik bangunan rumah yang di miliki oleh responden dapat dilihat pada tabel sebagai berikut:

Tabel 4.7 Kondisi Fisik Bangunan

\begin{tabular}{cccc}
\hline No & Kondisi rumah & Jumlah & Persentase (\%) \\
\hline 1 & Permanen & 3 & 13,04 \\
\hline 2 & Semi permanen & 9 & 39,13 \\
\hline 3 & Papan & 11 & 47,83 \\
\hline & Jumlah & $\mathbf{2 3}$ & $\mathbf{1 0 0}$
\end{tabular}

Sumber:Data Primer Desa Lakarinta (2018)

Berdasarkan tabel diatas menunjukan bahwa kondisi rumah responden berfariasi yaitu Permanen, sebanyak 3 responden atau dalam persentase $13,04 \%$, kemudian responden yang memiliki kondisi rumah semi permanen sebanyak 9 responden atau dalam persentase $39,13 \%$, sedangkan responden yang memiliki kondisi rumah yang papan sebanyak 11 responden atau dalam persentrase $47,83 \%$.

\section{d. Luas bangunan rumah}

Selain aspek kepemilikan rumah, hal ini dapat dilihat dari aspek perumahan yaitu kondisi luas rumah yang dimiliki oleh responden. Adapun bangunan rumah yang dimiliki oleh responden dapat dilihat pada tabel sebagai berikut:

Tabel 4.8. Luas Bangunan Rumah Responden

\begin{tabular}{cccc}
\hline No & Luas bangunan rumah & Jumlah & Persentase(\%) \\
\hline 1 & $102-131$ & 4 & 17,39 \\
\hline 2 & $7-101$ & 7 & 30,43 \\
\hline 3 & $40-70$ & 12 & 52,18 \\
\hline & Jumlah & $\mathbf{2 3}$ & $\mathbf{1 0 0}$ \\
\hline
\end{tabular}

Sumber:Data Primer Desa Lakarinta(2018)

Berdasarkan tabel diatas menunjukan bahwa responden yang memiliki luas bangunan rumah sebesar 102-131 yaitu sebanyak 4 responden dengan persentase 17,39\%,kemudian responden yang memiliki bangunan71- 101adalah sebanyak 7 responden atau dalam persentase $30,43 \%$, kemudian responden yang memiliki bangunan rumah 40-70 adalah 12 responden atau dalam persentase $52,18 \%$. 
4. Kondisi Ekonomi Responden

a. Pendapatan Responden

Dalam bisnis pendapatan adalah jumlah uang yang di terima dari aktivitasnya, kebanyakan dari penjualan produk dana jasa kepada pelanggan. Sedangkan bagi masyarakat nelayan yang ada di Desa Lakarinta Kecamatan Lohia adalah penerimaan yang di peroleh dari hasil usaha yang telah dikerjakan. Responden dalam penelitian ini umumnya bermata pencaharian sebagai nelayan.
Pendapatan

adalah penerimaan yang diterima oleh responden sebagai imbalan atas sesuatu pekerjaan atau jasa yang telah di lakukan setelah di kurangi dengan pengeluaran.

Dari hasil penelitian yang diperoleh bahwa pendapatan yang di terima responden bervariasi sesuai dengan pendapatan pekerjaan pokok yang ditekuni oleh mereka untuk memenuhi kebutuhan hidup keluarga.

Tabel 4.9. Tingkat Pendapatan Pokok Responden Setiap Bulannya

\begin{tabular}{cccc}
\hline No & $\begin{array}{c}\text { Jumlah pendapatan } \\
\text { setiapbulan (Rp) }\end{array}$ & Jumlah & Persentase(\%) \\
\hline 1 & $\geq$ Rp. 3.000 .000 & 10 & 43,47 \\
\hline 2 & Rp. 2.500 .000 & 6 & 26,09 \\
\hline 3 & Rp. 2.000 .000 & 4 & 17,39 \\
\hline 4 & $<$ Rp. 1.500 .000 & 3 & 13,05 \\
\hline & Jumlah & $\mathbf{2 3}$ & $\mathbf{1 0 0}$ \\
\hline
\end{tabular}

Sumber: Data Primer Desa Lakarinta(2018)

Berdasarkan tabel diatas menunjukan bahwa pendapatan pokok masyarakat nelayan di desa lakarinta yaitu $\geq$ Rp. 3.000.000 sebanyak 10 responden, atau dalam persentase 43,47\%, kemudian Rp. 2.500 .000 yaitu 6 responden, ataudalam persentase 26,09\%,kemudian Rp. 2.000 .000 yaitu sebanyak 4 responden atau dalam persentase $17,39 \%$, sedangkan untuk pendapatan < Rp. 1.500 .000 sebanyak 3 responden atau dalam persentase $13,05 \%$.

Berdasarkan pendapatan diatas dari segi pendapatan pokok yang di terima responden dapat di kategorikan sangat baik dimana sebanyak 23 responden memiliki pendapatan $\geq$ Rp. 3.000.000.

\section{b. Biaya kebutuhan responden per} hari

Masyarakat nelayan yang ada di Desa Lakarinta Kecamatan Lohia juga mengeluarkan biaya untuk memenuhi kebutuhan sehari-hari. Untuk mengetahui biaya kebutuhan responden dapat dilihat pada tabel berikut:

Tabel 4.10. Biaya Kebutuhan Responden Perbulan

\begin{tabular}{cccc}
\hline No & Biaya kebutuhan & Jumlah & Persentase(\%) \\
\hline 1 & Rp. 1.000.000-Rp. 1.350.000 & 9 & 39,13 \\
\hline 2 & Rp.1.350.000-Rp. 1.850.000 & 5 & 21,74 \\
\hline 3 & Rp. 1.850.000-Rp. 2.000.000 & 4 & 17,39 \\
\hline 4 & $\geq$ Rp.2.000,000 & 5 & 21,74 \\
\hline & Jumlah & 23 & 100
\end{tabular}

Sumber: Data Primer Desa Lakarinta(2018) 
Berdasarkan tabel diatas menunjukan bahwa kebutuhan responden per bulan pada kisaran antara Rp. 1.000.000-Rp. 1.350 .000 sebanyak 9 responden atau dalam persentase $39,13 \%$, kemudian pengeluaran responden pada kisaran Rp.1.350.000-Rp. 1.850.000adalah sebanyak 5 responden atau dalam persentase $21,74 \%$, kemudian pengeluaran responden kisaran antara Rp. 1.850,000-Rp..2.000000 sebanyak 4 responden atau dalam persentase $17,39 \%$, sedangkan pengeluaran responden kisaran $\geq$ Rp.2.000.000 adalah sebanyak 5 responden atau dalam persentase $21,74 \%$.

Dalam menghitung jumlah kebutuhan responden per bulan peneliti hanya menghitung jumlah uang yang dikeluarkan responden untuk membeli berbagai jenis kebutuhan seperti bensin, rokok, beras, senter dan kebutuhan lainnya. Akan tetapi, besarnya biaya kebutuhan responden berbeda-beda sebab jumlah uang dikeluarkan untuk membeli kebutuhan mereka sangat beragam. Hal ini tergantung dari jumlah tanggungan responden dalam keluarga. Semakin banyak tanggungan dalam keluarga semakin besar biaya yang dikeluarkan.

\section{PEMBAHASAN}

Berdasarkan hasil analisis kondisi sosial ekonomi menunjukan bahwa kondisi sosial ekonomi masyarakat nelayan di Desa Lakarinta Kecamatan Lohiamenunjukan suatu kondisi ekonomi tingkat sedang. Hal ini berdasarkan pada indikator yang ada di dalamnya seperti pendidikan, perumahan, kesehatan dan pendapatan. Dimana keempat indikator ini yaitu dilihat dari pendidikan masyarakat nelayan bahwa sebagian besar responden telah menamatkan pendidikan formalnya dan ini dapat meningkatkan taraf intelektualitas. Selain dapat meningkatkan taraf intelektualitas dapat pula masyarakat berpartisispasi terhadap pembangunan. Akan tetapi, apabila dilihat berdasarkan indikator penilaian kondisi pendidikan masyarakat nelayan di Desa Lakarinta dapat di kategorikan masih cukup. Hal ini dapat di lihat dari 23 responden Tamat SD sebanyak13 responden atau sebesar $17,39 \%$, asumsi pendidikan formal yang di tamatkan rata-rata hanya pendidikan formal tingkat SD.

Dilihat dari kondisi kesehatan responden masyarakat nelayan di Desa LakarintaKecamatan Lohia berada pada kriteria baik. Dimana tingkat kesadaran masyarakat nelayan akan kesehatan sangat tinggi dimana mereka sangat memperhatikan kebersihan lingkungan mereka. Selain itu juga, ketika mereka terserang penyakit mereka segera memeriksakan kesehatan mereka ke puskesmas setempat dengan alasan ke puskesmas pelayanannya yang baik dan cara pengobatan yang praktis, Masyarakat nelayan di Desa Lakarinta Kecamatan Lohia sudah tidak lagi pergi berobat kepada dukun.

Kemudian di lihat dari kondisi perumahan responden masyarakat nelayan di Desa Lakarinta Kecamatan Lohia dimana semua responden telah memiliki rumah sendiri. Dalam hal ini semua responden sudah tidak ada lagi yang kontrak atau menumpang samakeluarga, sehingga kondisi perumahan responden masyarakat nelayan berada pada kriteria yang sedang. Hal ini di tunjukan dengan yang ada di dalamnya seperti status kepemilikan rumah, keadaan kondisi rumah, sumber penerangan dan sumber air bersih.

Di lihat dari kondisi pendapatan responden masyarakat nelayan di Desa Lakarinta Kecamatan Lohia menunjukan bahwa semua responden memiliki pendapatan yang baik. Pendapatan responden setiap bulannya sebanyak 
Rp.3.000.000 yaitu 10 responden atau dalam persentase 43,47\%. Di dasarkan pada indikator penilaian tersebut maka pendapatan berada pada kriteria cukup baik.

Berdasarkan indikator menurut Badan Pusat Statistik tahun 2005 untuk mengetahui tingkat kesejahteraan masyarakat nelayan di Desa Lakarinta kecamatan Lohia menggunakan 8 pendekatan yaitu pendidikan, pendapatan, keadaan tempat tinggal, fasilitas tempat tinggal, kesehatan anggota keluarga, kemudahan mendapatkan pelayanan kesehatan, konsumsi atau pengeluaran rumah tangga dan kemudahan memasukan anak ke jenjang pendidikan yang lebih tinggi. Untuk lebih jelasnya dapat dilihat dalam tabel sebagai berikut

Tabel 4.11. Indikator Keluarga Sejahtera Menurut (BPS 2005)

\begin{tabular}{ccc}
\hline No & Indikator & Kriteria \\
\hline 1 & Pendidikan & Sedang \\
\hline 2 & Pendapatan & Tinggi \\
\hline 3 & Keadaan tempat tinggal & Baik \\
\hline 4 & Fasilitas tempat tinggal & Sedang \\
\hline 5 & Kesehatan anggota keluarga & Baik \\
\hline 6 & Kemudahan mendapatkan pelayanankesehatan & Baik \\
\hline 7 & Konsumsi pengeluaran rumah tangga & Sedang \\
\hline
\end{tabular}

Sumber : Data diolah 2018

Berdasarkan tabel indikator keluarga sejahtera menurut BPS Tahun 2005 menunujukan bahwa kondisi sosial ekonomi masyarakat nelayan di Desa Lakarinta berada pada tingkat keluarga sejahtera sedang. Hal ini dapat di lihat dari pendidikannya dimana antara 23 responden Tamat SD sebanyak 13 responden atau sebesar 56,52\%.Hal ini menunjukan bahwa pendidikan responden masih sedang. Kemudian dilihat dari pendapatan responden dimana sebanyak 23 responden setiap bulannya sebanyak $\geq$ Rp.3.000.000. yaitu 10 responden atau dalam persentase $43,47 \%$, dimana menurut BPS 2005 tingkat pendapatan responden berada pada tingkat tinggi. Kemudian dilihat dari keadaan tempat tinggal dimana dari 23 responden sebanyak 9 responden atau dalam persentase $17,40 \%$ semi permanen, sehingga dikategorikan baik.

Selain itu didukung juga dengan luas bangunan rumah, jenis lantai, jenis dinding, dan sumber penerangan. Kemudian di lihat dari fasilitas tempat tinggal responden berada pada tingkat sedang, hal ini dapat dilihat pada perabot rumah, jenis kendaraan yang digunakan. Kemudian dilihat dari keadaan kesehatan anggota keluarga dimana dalam 6 bulan terakhir responden memiliki anggota keluarga yang sakit dimana anak-anak mereka menderita penyakit flu dan batukbatuk akibat cuaca yang tidak menentu. Kemudian dalam 6 bulan terakhir responden juga menderita penyakit seperti demam, sakit pinggang, rematik, dan asam urattetapi responden segera memeriksakan kesehatan di puskesmasserta tenaga medis lainnya, sehingga kesehatan responden berada pada tingkat sedang. Kemudian dilihat dari kemudahan mendapatkan pelayanan kesehatan responden berada pada tingkat sedang hal ini dapat dilihat dimana responden selalu memeriksakan kesehatannya di puskesmas serta tenaga medisnya pelayanannya bagus dan praktis. Kemudian dilihat dari konsumsi pengeluaran rumah tangga dimana dari 23 responden kemudian pengeluaran responden kisaran antara Rp. 1.000.000Rp. 1.350.000 sebanyak 9 responden atau dalam persentase $39,13 \%$, sehingga untuk 
konsumsi pengeluaran rumah tangga berada pada tingkat sedang.

\section{KESIMPULAN}

Berdasarkan tabel indikator keluarga sejahtera menurut BPS tahun 2005 menunjukan bahwa kondisi sosial ekonomi masyarakat nelayan di Desa Lakarinta Kecamatan Lohia berada pada tingkat keluarga sejahtera sedang. Hal ini dapat dilihat dari:

1. Pendidikan dimana dari 23 responden Tamat SD sebanyak 13 responden atau sebesar $56,52 \%$, pendidikan formal yang ditamatkan hanya pada tingkat SD menurut BPS 2005 tingkat pendidikan responden berada pada tingkat rendah.

2. Kesehatan anggota keluarga dimana 6 bulan terakhir hanya sebesar 30,43\% responden memiliki anggota keluarga yang sakit dimana anak-anak mereka menderita penyakit flu dan batuk-batuk akibat cuaca yang tidak menentu, sehingga untuk kesehatan responden berada pada tingkat baik.

3. Kemudahan mendapatkan pelayanan kesehatan responden berada pada tingkat baik.

4. Keadaan tempat tinggal dimana 23 responden 9 responden memiliki rumah semi permanen sehingga dikategorikan baik selain itu didukung juga dengan luas bangunan rumah, jenis dinding, dan sumber penerangan.

5. Fasilitas tempat tinggal responden berada pada tingkat sedang, hal ini dapat dilihat perabot rumah tangga dan jenis kendaraan yang digunakan.

6. Pendapatan rata-rata perbulan berkisar antara $\geq$ Rp. 3.000.000 dimana menurut BPS 2005 tingkat pendapatan responden berada pada tingkat baik.

7. Konsumsi pengeluaran rumah tangga rata-rata perbulan berkisar antara Rp. 1.000.000-Rp. $\quad 1.350 .000$ sehingga untuk konsumsi pengeluaran rumah tangga berada pada tingkat sedang.

\section{DAFTAR PUSTAKA}

Aditiwati, dkk. 2003. Cultur Campuran dan Faktor Lingkungan dan Mikroorganismeyang berperan dalam Fermentasi Tea-Cider. Departemen Biologi-FMIPA Institut Teknologi Bandung. PROC.ITM Sains dan Tek. 35 A, No (2), 147-162.

Afiah, Afiana. 2014. "Pengaruh Implementasi Full Day School Terhadap Tingkat Kecerdasan Emosional dan Penyesuaian Sosial Di MI Sultan Agung Sleman". Yogyakarta: Fakultas Tarbiyah dan Keguruan Universitas Islam Negeri Sunan Kalijaga.

Afriyenita, Erman Har dan Erwinsyah Satria. 2013. "Peningkatan Aktivitas dan Hasil Belajar Siswa Kelas V pada Pembelajaran IPA dengan Strategi Aktif Tipe True or False di SD Kartika 1-10 Padang." Dalam E-Jurnal Bung Hatta2 (2). Diakses pada 7 Desember 2015 (http://ejurnal.bunghatta.ac.id).

Ajang Mulyadi. (2004). Akuntansi untuk SMAKelas XI. Bandung

BadanPusat Statistik. 2013.Indikator Penilaian Sosial EkonomiMasyarakat.Sulawesi Tenggara.

Badan Pusat Statistik, Kecamatan Lohia 2016.

Ema \& Mukhtar Widodo, Konstruksi ke Arah Penelitian Deskriptif, Ayyrrouz, Yogyakarta, 2000.

Horngren, Charles T., et al. 2008. Akuntansi Biaya. Edisi 7. PT INDEKS kelompok GRAMEDIA: Jakarta. 
Jurnal Penelitian Pendidikan Geografi Volume 4 No. 1 Januari 2019

Kavie. (2009). Pengertian Pendidikan,

(Internet). [http:/kavie deign.

Indonesia Forum.net.htm].

Kusnadi.2009. Keberdayaan Nelayan dan

Dinamika Ekonomi Pesisir.Pusat

Penelitian wilayah pesisir dan

pulau-pulau kecil. Jember:

lembaga penelitian universitas

jember. 152 halaman.

Oktama. 2013. Pengaruh Kondisi Sosial Ekonomi terhadap Tingkat Pendidikan Anak keluarga Nelayan di Kelurahan Sugihwaras Kecamatan Pemalang Kabupaten Pemalang. Semarang: Jurusan Geografi FIS UNES. 